\title{
IRENEUSZ ZIEMIŃSKI
}

\section{O RZECZYWISTEJ I NIEUCHRONNEJ IDOLATRYCZNOŚCI RELIGII — ODPOWIEDŹ POLEMISTOM}

Odpowiedź na uwagi polemiczne, zgłoszone do książki Religia jako idolatria (ZIEMIŃSKi 2020b) ${ }^{1}$, podzielę na sześć części. Pierwsza dotyczy zastosowanej przez Krytyków strategii dyskusji, odwołującej się do logicznych możliwości i podważającej uzasadnienie tezy o istotowej idolatryczności religii. Tematem części drugiej jest proponowana przez Błażeja Gęburę „religia zero”, trzeciej zaś — przypadkowy akt religijnej czci. W części czwartej podejmę kwestię ontycznego dystansu, uważanego przez Polemistów za niezbędny warunek religii, w części piątej zaś - problem nadmiernego rozszerzenia pojęcia idolatrii. Ostatnią część poświęcę problemowi eliminacji religii z kultury.

\section{UZASADNIENIE TEZY}

Najskuteczniejszą formą falsyfikacji głównej tezy książki Religia jako idolatria byłoby podanie przykładu zjawiska religijnego, które nie jest idolatryczne. Jeśli bowiem twierdzenie o nieuchronnej idolatryczności religii jest fałszywe, to musiało dojść przynajmniej raz do bezpośredniego (w żaden sposób niezapośredniczonego) poznania Boga lub oddania Mu czci bez udziału idoli (w postaci rytuałów, gestów czy obrazów); niestety, żaden z Polemistów takiego przykładu nie podał. Ten brak empirycznej falsyfikacji

Prof. dr hab. IRENEuSz ZIEMIŃSKI - Uniwersytet Szczeciński, Wydział Humanistyczny, Instytut Filozofii i Kognitywistyki; adres do korespondencji: ul. Krakowska 79, 71-017 Szczecin; e-mail: Ireneusz.Zieminski@usz.edu.pl; ORCID: https://orcid.org/0000-0003-4686-8625.

${ }^{1}$ Dziękuję Polemistom za lekturę książki i zgłoszone do niej uwagi krytyczne (GĘBURA 2021, 357-365; IwANICKI 2021, 367-380), a także Redaktorowi Naczelnemu Roczników Filozoficznych, prof. Jackowi Wojtysiakowi, za publikację polemik wraz moją odpowiedzią. 
tezy o idolatryczności religii sugeruje, że nie są znane zachowania religijne wolne od idolatrii.

Równie obiecującą strategią falsyfikacji głównej tezy książki byłaby nieidolatryczna interpretacja jednego $\mathrm{z}$ opisanych $\mathrm{w}$ niej zjawisk religijnych. Polemiści mogli wskazać, na przykład, że Eucharystia nie ma znamion idolatrii, nie polega bowiem na utożsamieniu ciała i krwi Chrystusa z fizycznymi postaciami chleba i wina. W tym celu należało przedstawić dowód, że - pomimo braku zmian w wyglądzie zewnętrznym, smaku i składzie chemicznym - postacie eucharystyczne nie są chlebem i winem, lecz realnym ciałem i krwią Boga. Podobnie można było podać taką interpretację Kościoła rzymskiego, przy której kler nie zastępuje Boga ani nie przejmuje Jego zbawczych prerogatyw. Skoro jednak Polemiści nie zakwestionowali żadnego z podanych przykładów, to znaczy, że zostały one dobrane trafnie. $\mathrm{W}$ takim zaś razie twierdzenie, że religia jest $\mathrm{z}$ istoty idolatrią, można zaakceptować przynajmniej w odniesieniu do dotychczasowych jej dziejów.

$Z$ trudności tej zdaje sobie sprawę Błażej Gębura, deklarując, że rezygnuje z przykładów historycznych, aby uniknąć zarzutu konfesyjności. Strategia ta jest jednak kłopotliwa już choćby dlatego, że w filozoficznych sporach na temat religii nie sposób uniknąć zarzutu bądź to konfesyjności, bądź nieznajomości badanego zjawiska $\mathrm{z}$ powodu braku wiary. $\mathrm{Na}$ zarzut braku obiektywizmu są zatem narażone zarówno osoby religijne, jak i niereligijne $^{2}$. Z tego powodu należy żałować, że w debacie nad książką o idolatrii brakuje perspektywy konfesyjnej. Niewykluczone przecież, że tylko wyznawca islamu jest w stanie przedstawić dowód (przekonujący także dla osób niebędących muzułmanami), że sakralizacja prawa koranicznego nie zastępuje czci należnej Bogu. Podobnie nie da się wykluczyć, że tylko katolik potrafi dowieść (w sposób przekonujący dla niekatolików), że kapłan sprawujący Eucharystię nie zastępuje Chrystusa, nie zawłaszcza Go ani nie reglamentuje Jego obecności w świecie. Przykłady te świadczą, że Polemiści nie tylko nie mieli powodów do porzucania konfesyjnego punktu widzenia, lecz przeciwnie - mieli powody, aby go zająć (przynajmniej na użytek dyskusji). Osoby wierzące wszak mogą podać racje, dla których trwają przy swoich idolach, preferując jedne, odrzucając zaś inne ${ }^{3}$.

\footnotetext{
${ }^{2}$ Kłopoty badaczy religii w żartobliwej formie opisywał literacko Karel Čapek w Fabryce Absolutu. Por. ČAPEK 2015.

${ }^{3}$ Błażej Gębura zresztą, wbrew swojej deklaracji, nie porzucił całkowicie konfesyjnego punktu widzenia, interpretując podziw dla największego drzewa w kategoriach teistycznych (a nawet chrześcijańskich). Z kolei Marcin Iwanicki zapewnia, że interesuje go głównie chrześcijaństwo;
} 
Rezygnując z prowadzenia sporu na płaszczyźnie historii i wiary, Polemiści obrali mniej skuteczną strategię, wskazując, że zaprezentowane w książce uzasadnienie nieuchronnej idolatryczności religii jest niewystarczające. Krytycy zatem nie dyskutują z moim poglądem wprost, lecz pośrednio; nie próbują wykazać fałszywości tezy, lecz jedynie brak jej uzasadnienia. Problemem jest jednak to, że obalenie argumentacji nie jest obaleniem tezy; jeśli zatem nawet uzasadnienia tezy o idolatryczności religii są błędne, mgliste lub niewystarczające, to nie wynika stąd, że równie błędna jest teza, ani tym bardziej, że prawdziwa jest teza przeciwna. Wprawdzie wolno sądzić, że racjonalne jest uznawanie za prawdę jedynie tez udowodnionych, to jednak prawo takie mają obie strony sporu; w takim razie również zwolennik tezy o idolatryczności religii może jej bronić dopóty, dopóki nie zostanie mu przedstawiony dowód prawdziwości tezy przeciwnej. Ponieważ jednak tego typu zabiegi retoryczne nie przybliżają do zrozumienia natury religii, lepiej je porzucić.

W przedstawionych polemikach obecna jest również bardziej owocna strategia argumentacyjna, polegająca na próbie wykazania niespójności tezy o idolatryczności religii, $\mathrm{z}$ jednej bowiem strony idole niszczą religię,

tym bardziej dziwi brak kontrprzykładu do tezy o istotowej idolatryczności religii zaczerpniętego z wiary. Jednym z powodów jest, jeśli dobrze rozumiem Marcina Iwanickiego, chęć odróżnienia zjawisk historycznie przygodnych (prześladowanie innowierców, pozycja kleru) od istoty religii. Problem polega jednak na tym, że dzieje chrześcijańskiej przemocy nie są wypaczeniem doktryny nauki Jezusa, lecz mają w niej swe źródło. Skoro bowiem ludzie, którzy nie przyjmą Ewangelii, zostaną potępieni (Mt 13,37-43, 2 Tes 1,6-10), to łatwo stąd wyprowadzić wniosek, że należy zmusić człowieka do wiary, nawet za cenę śmierci czy cierpień w życiu doczesnym; lepiej wszak wejść do nieba ślepym i chromym, niż trafić do piekła widzącym i wolnym od wszelkich niepełnosprawności (Mt 18,8-9, Mk 9,43-49). Równie wymowne jest przykazanie miłości, które na pierwszym miejscu stawia obowiązki wobec Boga, na drugim dopiero - wobec bliźnich (Mt 22, 36-40). W sytuacji konfliktu zatem między miłością Boga a miłością do człowieka należy opowiedzieć się za Bogiem; kto zresztą kocha bardziej rodziców czy dzieci niż Jezusa, nie jest Go godzien (Mt 10,37). W skrajnym przypadku zatem możliwe jest użycie przemocy wobec człowieka w imię rzekomej miłości Boga. Samo zresztą przykazanie miłości bliźniego nakazuje troskę o jego najwyższe dobro, czyli wiecznie zbawienie; znaczy to, że można poświęcić szczęście doczesne człowieka, aby ratować go przed piekłem. Przemoc religijna wynika zatem z troski o zbawienie grzeszników, pogan czy innowierców, będąc dopełnieniem mesjańskiego przesłania Chrystusa. Z kolei problem kleru nie sprowadza się (wbrew opinii Marcina Iwanickiego) do megalomanii niektórych księży, lecz do samej instytucji kapłaństwa i jej eklezjologicznego uzasadnienia, zgodnie z którym człowiek sprawujący Eucharystię ma nieograniczoną władzę nad Chrystusem. Nie chodzi zatem o psychologię kapłanów, lecz o teologię kapłaństwa; w centrum rzymskiego katolicyzmu bowiem nie stoi Chrystus zmartwychwstały, nad którym człowiek nie ma władzy, lecz Chrystus eucharystyczny, nad którym pełnię władzy mają kapłani, przejmujący w ten sposób boskie prerogatywy. 
przysłaniając, a nawet zastępując Boga, z drugiej — są jedynym narzędziem, za którego pomocą można nawiązać z Nim kontakt; idole zatem równocześnie uniemożliwiają poznanie Boga i je warunkują. Zdaniem Polemistów tymczasem prawdziwy może być tylko jeden człon alternatywy: albo idole warunkują kontakt z Bogiem, albo go wykluczają.

W odpowiedzi należy zauważyć, że niespójność ta nie jest wadą interpretacji religii jako idolatrii, lecz nieusuwalną cechą religii, będącej przedsięwzięciem niemożliwym właśnie dlatego, że jej celem jest nawiązanie bezpośredniego kontaktu z niedosiężnym Bogiem (świętością). Na problem ten wskazał św. Paweł, twierdząc, że w doczesności Boga można widzieć jedynie w zwierciadle, nie zaś twarzą w twarz (1 Kor 13,12); nie ma tymczasem wątpliwości, że obraz odbity w zwierciadle Bogiem nie jest. Apostoł potwierdza zatem, że w aktualnych warunkach epistemicznych możemy obcować jedynie z idolami, których nie należy uważać za pierwowzór ani nawet za jego adekwatny obraz, każde wszak zwierciadło jest nieuchronnie zwierciadłem krzywym. Wprawdzie Apostoł Paweł wierzył, że po śmierci zobaczymy Boga takim, jaki jest (1 Kor 13,12), filozofowi jednak trudno uznać tę obietnicę za rozstrzygającą, nie istnieją bowiem żadne weryfikowalne dane, potwierdzające realność życia po śmierci, w którym będzie można poznać bezpośrednio obiekt religijnych pragnień ${ }^{4}$. Niezależnie jednak od tego, czy ludzie zaufają Pawłowi (marząc o śmierci, aby połączyć się z Bogiem) ${ }^{5}$ czy filozofom, ostrzegającym, że śmierć jest ostatecznym kresem życia,

\footnotetext{
${ }^{4}$ Odwołanie się do hipotezy życia przyszłego jako potwierdzenia naszych przypuszczeń (nazywane weryfikacją eschatologiczną), jest — z punktu widzenia sporu filozoficznego strategią najdosłowniej samobójczą; w gruncie rzeczy bowiem, aby sprawdzić wiarygodność swoich hipotez, należałoby umrzeć, co jest wymogiem irracjonalnym. Por. JUDYCKI i SzUBKA 1985, 143-153. Pomimo kłopotów, związanych z weryfikacją eschatologiczną, Marcin Iwanicki uważa, że po śmierci Bóg zniesie wszystkie ograniczenia (i to nie tylko ludzkie, lecz także innych stworzeń), dzięki czemu będziemy mogli Go zobaczyć takim, jaki jest, bez pośrednictwa idoli. Można jednak zapytać, dlaczego dobry Bóg nie chce się objawić w życiu doczesnym, lecz karząc wszystkich za grzech pierwszych rodziców - utrzymuje nas w błędzie; nic przecież nie stoi na przeszkodzie, aby już w obecnym życiu ukazał się nam twarzą w twarz. Skoro tego nie czyni, to albo nie chce się objawić, co każe wątpić o Jego dobroci, albo - co sugerowałem w książce - nie jest tego $\mathrm{w}$ stanie dokonać $\mathrm{z}$ racji ontycznego dystansu między nami a Nim. Osobnym problemem jest to, że zasada „w niebie się przekonamy”, nie jest argumentem rozstrzygającym; jeśli bowiem życie przyszłe nie istnieje, to nie będzie podmiotu, który marzył, że zobaczy Boga, weryfikując w ten sposób swoje ziemskie nadzieje.

${ }^{5}$ „Dla mnie bowiem życiem jest Chrystus, a śmierć zyskiem. Jeśli jednak życie umożliwiłoby mi owocną pracę, nie wiedziałbym, co wybrać. Nęci mnie jedno i drugie. Pragnę rozstać się z życiem i być z Chrystusem, co byłoby lepsze, chociaż pozostanie przy życiu byłoby ze względu na was bardziej pożyteczne" (Ef 1,21-25). Wszystkie cytaty biblijne pochodzą z Biblii Poznańskiej (Pismo Święte. Stary i Nowy Testament 2005).
} 
argumentacja Apostoła potwierdza, że w doczesności pragnienie religijne nie może zostać zaspokojone ${ }^{6}$. Równocześnie jednak Paweł potwierdza, że nie mielibyśmy żadnego dostępu do Boga, gdyby nie Jego zwierciadlane odbicie. Znaczy to, że religia jest przedsięwzięciem paradoksalnym, idole odgrywają bowiem dwie, wzajemnie się wykluczające role: $\mathrm{z}$ jednej strony są warunkiem odnoszenia się do Boga, z drugiej — przysłaniają Go, a nawet zastępują.

Poważniejszy problem, na który zwróciłem uwagę w zakończeniu książki, dotyczy niemożliwości przeprowadzenia nieidolatrycznej krytyki idolatryczności religii. Powodem jest już samo przeciwstawienie idola - autentycznemu obiektowi religijnej czci (Bogu, świętości); w gruncie rzeczy bowiem mamy do czynienia z przeciwstawieniem jednego idola innemu, ponieważ także słowa „Bóg” czy „świętość” są nieadekwatnym obrazem rzeczywistości, którą chcemy za ich pomocą opisać. Z tego powodu nie tylko nie jest możliwa nieidolatryczna religia, lecz także - nieidolatryczna krytyka religii; jedne idole można jedynie demaskować za pomocą innych idoli, nie wiedząc nawet, czy istnieje obiekt, któremu chcemy za ich pomocą oddać cześć. Zdaniem Marcina Iwanickiego dylemat ten podważa tezę książki: jeśli bowiem określenia typu „świętość” czy „Bóg” są idolami, to nie można ich użyć w argumentacji wskazującej na idolatryczność religii; jeśli zaś nie są idolami, to mamy religię wolną od idolatrii. Niestety, wbrew marzeniom Polemisty, sytuacja jest bardziej złożona, zachodzi bowiem ewentualność trzecia, zgodnie z którą przywołane określenia są idolami i właśnie dlatego nie jest możliwa religia nieidolatryczna, oparta na bezpośrednim poznaniu Boga $^{7}$. Dramatyczne „albo-albo”, przywołane przez Polemistę, potwierdza, że nie jesteśmy w stanie wyzwolić się z zaklętego kręgu idoli, o których nie wiemy nawet, czy odnoszą się do jakiegokolwiek obiektu, różnego od nich.

Niemożliwość przeprowadzenia nieidolatrycznej krytyki religii nie dowodzi też, że istnieje religia wolna od idolatrii ani że idolatryczna krytyka

\footnotetext{
${ }^{6}$ Problemu nie usunie (proponowane przez Marcina Iwanickiego) odróżnienie między błędną a trafną identyfikacją słowa „Bóg”; skoro bowiem mamy do czynienia jedynie z idolami, to nie jest możliwa identyfikacja poprawna (zwłaszcza że nie wiemy nawet, czy istnieje jej domniemany obiekt).

${ }^{7} \mathrm{Z}$ tego powodu postulowane przez Marcina Iwanickiego rozróżnienia scholastyczne (eksploatowane na gruncie analitycznej filozofii religii), dotyczące stopni i rodzajów pośredniości poznania, nie doprowadzą do zmiany wniosku; skoro bowiem obiektu religijnej czci nie poznajemy bezpośrednio (bez żadnych pośredników, także przeźroczystych — cokolwiek miałoby takim pośrednikiem być), to ludzka wiedza religijna zawsze będzie skażona idolatrią. Sytuacja nie zmieni się dopóty, dopóki jakaś osoba nie doświadczy Boga bezpośrednio i nie podzieli się $\mathrm{z}$ innymi swoim doświadczeniem; mogłaby to być nawet osoba przebywająca w niebie (żeby a priori nie wykluczać scenariusza nakreślonego przez Marcina Iwanickiego).
} 
religii jest strategią samobójczą (jak sugeruje Marcin Iwanicki). Z podobną sytuacją mamy bowiem do czynienia $w$ innych sytuacjach epistemicznych, chociażby w percepcji. To przecież, że jedną percepcję uznajemy za wiarygodną, inną zaś odrzucamy jako iluzoryczną, nie dowodzi, że w pierwszym przypadku mieliśmy bezpośredni dostęp do świata, w drugim zaś — do subiektywnego i fałszywego obrazu skonstruowanego przez umysł. W praktyce poznawczej uznajemy bowiem wiarygodność tych percepcji, które zostały potwierdzone, także przez innych ludzi, odmawiamy zaś wiarygodności tym, które są sporadyczne i nietypowe. O ile jednak w przypadku percepcji możliwa jest pośrednia weryfikacja wyników, o tyle w przypadku religijnych rytuałów nie jesteśmy w stanie sprawdzić, które są skuteczną formą przebłagania Boga czy oddania $\mathrm{Mu} \mathrm{czci}^{8} . \mathrm{Z}$ tego powodu akceptujemy (lub odrzucamy) określone idole dlatego, że są zgodne (lub niezgodne) z innymi naszymi przekonaniami. Jeśli zatem ktoś uważa, że Bóg jest dobry dla swoich stworzeń, to nie składa Mu ofiar z ludzi ani zwierząt; ten z kolei, kto uważa, że Bóg musi napić się krwi, aby mieć siłę do podtrzymania wegetacji $\mathrm{w}$ przyrodzie, to ofiary takie uzna za konieczne. W obu przypadkach mamy do czynienia $\mathrm{z}$ idolami, pierwowzór bowiem pozostaje nieznany. Wbrew zatem sugestii Marcina Iwanickiego krytyka jednych idoli (ofiary krwawe) z perspektywy innych idoli (ofiary bezkrwawe) jest zasadna; nawet nie znając Boga, wolno sądzić, że jedne formy kultu są gorsze (mniej adekwatne) od innych.

Przykład ten potwierdza, że idolatryczność religii jest szczególnym przypadkiem kantowskiego fenomenalizmu, w myśl którego znamy tylko zjawiska, a nie rzeczy w sobie. Wprawdzie Kant nie uniknął niespójności (skoro rzeczy w sobie są niepoznawalne, to nie można wiedzieć nawet tego, że są niepoznawalne), fakt ten jednak w niczym nie zmienia naszej sytuacji epistemicznej, nadal bowiem znamy tylko zjawiska. Podobnie można zarzucać Kantowi, że jego krytyka umysłu była niespójna, ponieważ (zgodnie z przyjętym założeniem) mógł znać umysł tylko jako zjawisko; w takim

${ }^{8}$ W latach 1450-1454 na ziemiach zamieszkiwanych przez Azteków zapanowała susza, a w jej efekcie — głód. Kapłani uznali, że powodem jest brak odpowiedniej ilości ludzkiej krwi, dostarczanej bogom. Wtedy wodzowie trzech państw (Tenochtitlan, Huexotzingo, Tlaxcala) zawarli układ o podjęciu wojny tylko po to, aby zdobyć odpowiednią liczbę jeńców, przeznaczonych na ofiary religijne. Po zakończeniu walk i złożeniu olbrzymiej liczby ofiar w $1455 \mathrm{r}$. spadły obfite deszcze. Por. Frankowska 1987, 137-139. Analogicznie ma się sprawa z Eucharystią jako pokarmem, mającym gwarantować życie wieczne, nie da się wszak sprawdzić, czy osoby zmarłe, które na ziemi spożywały konsekrowany chleb i wino, rzeczywiście dostąpiły nieba. 
jednak razie jego ustalenia nie są wiążące. Jeśli natomiast opisywał ludzki umysł jako rzecz w sobie, to podważył własną tezę, że można znać jedynie zjawiska. Argument ten jednak nie obala wyników Kantowskiej krytyki; skutecznym ich podważeniem byłoby wszak dopiero podanie przykładu posiadanej przez nas wiedzy o rzeczach w sobie. Podobny wniosek nasuwa się w związku z idolatrią; to, że idole można krytykować tylko z perspektywy innych idoli, nie dowodzi, że jakaś religia jest od nich wolna. Tak samo zatem jak w sferze poznania jesteśmy zamknięci w obrębie zjawisk, tak w sferze religii jesteśmy zamknięci w sferze idoli; w ten sposób tracą ważność kontrprzykłady, dotyczące cząstkowego poznania nieskończonych zbiorów, przyrody czy piękna.

Ostatnią ze strategii zastosowanych przez Polemistów są eksperymenty myślowe odwołujące się do logicznych możliwości. Zdaniem Krytyków bowiem, nawet jeśli $\mathrm{w}$ dotychczasowych dziejach nie pojawił się nieidolatryczny akt czci, to można go przynajmniej pomyśleć. Marcin Iwanicki uważa wręcz, że wszystkie akty religijne są idolatryczne jedynie od strony człowieka, Bóg bowiem (z racji swojej wszechwiedzy) może je rozpoznać i przyjąć jako nieidolatryczne. W takim zaś razie idolatria nie jest groźna, wszystkie bowiem akty czci odnoszą się do Boga; wprawdzie ludzie obcują z idolami, to jednak Bóg wie, że celem religii nie jest oddawanie czci idolom, lecz Jemu. Obiektem czci jest zatem każdorazowo On sam.

W odpowiedzi należy zauważyć, że Bóg postulowany przez Marcina Iwanickiego jest zbyt tolerancyjny, nie powinien bowiem przyjmować wielu aktów czci, zwłaszcza ofiar z ludzi i zwierząt jako (rzekomo) nieidolatrycznych; przyjmując je okazuje się moralnym relatywistą. Wniosek ten podważa nie tylko zasadność patrzenia na idolatrię religijną z perspektywy Boga (dla którego ma ona nie być idolatrią), lecz także metodę eksperymentów myślowych. Tymczasem, zdaniem Polemistów, warunkiem uznania twierdzenia o istotowej idolatryczności religii za prawdziwe jest brak wszelkich kontrprzykładów, także logicznie możliwych; wymóg ten jest jednak zbyt radykalny, podważając wszelki racjonalny dyskurs. Odwołując się wszak do logicznie możliwego stanu rzeczy, nie można go interpretować w izolacji, lecz należy uwzględnić wszystkie konsekwencje, do jakich musiałoby dojść, gdyby faktycznie zaistniał. Ilustracją jest - możliwe do pomyślenia zmartwychwstanie konkretnego człowieka. Dopóki uznajemy je za czysto logiczną możliwość, w niczym nie zmienia ono naszego obrazu świata, w którym umarli nie zmartwychwstają, a śmierć pozostaje ostatecznym i nieodwracalnym kresem życia. Uznając jednak taką możliwość za argument 
przeciwko tezie o nieodwracalności śmierci, zmienilibyśmy radykalnie obraz świata; ten bowiem, kto powstał z martwych, musi gdzieś przebywać, zostać rozpoznany, a także ponownie umrzeć lub istnieć wiecznie. Jeśli zostawił majątek, który przypadł spadkobiercom, to jego zmartwychwstanie musiało skomplikować sytuację własnościową; podobnie kłopotliwa stałaby się sytuacja rodzinna, gdyby wdowa po zmarłym wyszła ponownie za mąż. Bez wyliczania dalszych komplikacji widać, że konsekwencje faktycznego zmartwychwstania jednej osoby są niewyobrażalne. Jeśli zatem odwołujemy się do logicznie możliwych stanów rzeczy, to musimy uwzględnić nie tylko ich niesprzeczność, lecz także skutki, do jakich ich ewentualne zaistnienie musiałoby doprowadzić; wówczas może się okazać, że nie są one empirycznie możliwe, wobec czego ich wartość dowodowa jest znikoma. Analogicznie byłoby w przypadku urzeczywistnienia się - sugerowanej przez Polemistów - możliwości nieidolatrycznego aktu czci; gdyby do niego doszło, to wiele obecnych praktyk religijnych zostałoby porzuconych (nawet jeśli niektóre grupy wyznawców mogłyby chcieć pozostać przy swoich idolach). Co ważniejsze jednak, zmianie uległoby pojęcie człowieka, który okazałaby się istotą zdolną do bezpośrednich relacji z Bogiem. Świadczy to, że nie wystarczy odwołać się do samej możliwości nieidolatrycznego aktu czci, lecz należy również podać empiryczne warunki, w jakich mógłby on zostać spełniony; tego jednak Polemiści nie uczynili, zdając sobie zapewne sprawę z ograniczeń empirycznych. Skoro jednak logicznie możliwe akty nieidolatrycznej czci nigdy nie będą mogły zostać urzeczywistnione, to nie obalają tezy głoszącej, że religia jest idolatrią.

Odwoływanie się do czysto logicznych możliwości jako kontrprzykładów, mających falsyfikować tezy ogólne, prowadziłoby też do paraliżu nauki, nie da się wszak sformułować żadnego prawa wykluczającego wszystkie możliwe kontrprzykłady. Nawet prawo grawitacji nie wyklucza możliwości, że samobójca, który wyskoczył z wieżowca, pofrunie w przestworza, zamiast spaść na ziemię. Analogicznie jest $\mathrm{z}$ tezą o nieuchronnej idolatryczności religii; wprawdzie można pomyśleć religię wolną od idolatrii, to jednak dopóki nie zostanie spełniony choćby jeden nieidolatryczny akt czci, pozostaje $\mathrm{w}$ mocy twierdzenie, że religia jest idolatrią. Bardziej zresztą szkodliwe dla religii jest odwoływanie się do czysto hipotetycznych sytuacji niż idolatria jako skutek ludzkiej skończoności. Wymyślając wszak kolejne logicznie możliwe sytuacje, przekształcamy religię w baśń, opowiadającą nie tylko o Bogu, lecz także o diabłach, aniołach, krasnoludkach, nimfach czy elfach. Wprawdzie jest logicznie możliwe, że stwory te istnieją, tajemniczo 
wpływając na nasz los, to jednak trudno na takiej hipotezie budować poważne relacje z Bogiem. Podobnie jest do pomyślenia, że cień Apostoła uzdrawia chorych (Dz 5,15-16), z pewnością jednak nie należy na takiej możliwości budować ani religii, ani medycyny. Odwołując się do możliwości logicznych, należy także uwzględnić stopień ich prawdopodobieństwa; w przypadku nieidolatrycznego aktu czci jest ono zerowe z racji ontycznej przepaści między ludźmi a Bogiem.

Szczególnym przypadkiem strategii odwołującej się do logicznych możliwości jest „religia zero”; ponieważ jednak Autor zarzutu widzi w niej konieczny element (warunek) każdej religii historycznej, należy go omówić osobno.

\section{2. „RELIGIA ZERO”}

Błażej Gębura przekonuje, że niezbędnym warunkiem powstania religii jest wyjątkowe, niczym niezapośredniczone (nieidolatryczne) doświadczenie Boga, dostępne założycielowi. Idolatria pojawia się dopiero później, kiedy to religia staje się fenomenem społecznym, a pierwotne doświadczenie ulega degeneracji.

W pierwszej kolejności należy zauważyć, że - wbrew nadziejom Błażeja Gębury - idolatria nie pojawia się dopiero w momencie uspołecznienia doktryny czy kultu. Przeciwnie, mamy z nią do czynienia już w chwili pierwotnego doświadczenia religijnego, nawet gdy ma ono charakter prywatny. Założyciel nowej religii bowiem nie widzi Boga twarzą w twarz, lecz tworzy Jego własny wizerunek; jeśli zatem doszło do objawienia się Boga, to osoba, która go doznała, mogła je odkryć i zrozumieć jedynie na swój własny (czysto ludzki i skończony) sposób. Znaczy to, że źródłowe doświadczenie religijne ma charakter idolatryczny, o jego charakterze bowiem nie decyduje jedynie przedmiot (Bóg, świętość), lecz także sposób jego poznania przez podmiot. W takim zaś razie idolatria nie jest skutkiem uspołecznienia religii, lecz skończonej natury człowieka. Sam zresztą Autor zarzutu przyznaje, że „religia zero” jest idolatryczna, chociaż w mniejszym stopniu niż inne religie; w ten sposób potwierdza słuszność tezy bronionej w książce Religia jako idolatria.

Pozorna różnica zdań bierze się prawdopodobnie z przyjętego przez Polemistę założenia, zgodnie z którym istnieją tylko dwie możliwości: albo pierwotne doświadczenie religijne oznacza bezpośrednie poznanie Boga, albo jest idolatryczne. Jeśli zachodzi pierwsza ewentualność, to istnieje przynajmniej jedno zjawisko religijne niebędące idolatrią; jeśli natomiast 
zachodzi druga ewentualność, to nie można zrozumieć powstania religii. Tymczasem istnieje jeszcze trzecia możliwość: pierwotne doświadczenie Boga jest idolatryczne, daje jednak początek religii. Błażej Gębura nie bierze jej pod uwagę dlatego, że za warunek powstania religii uznaje nieidolatryczne doświadczenie Boga; w ten sposób jednak przesądził sprawę rzekomej nieidolatryczności religii na poziomie definicji, chociaż przykładu spełniającego taką definicję nie podał. Religie tymczasem powstają dlatego, że jakaś osoba (lub grupa osób) odkrywa nowy obraz Boga. Jeśli znajdzie współwyznawców, to religia ma szansę przetrwać; jeśli nikt orędzia nie przyjmie, religia ginie.

$\mathrm{Z}$ kolei degeneracja religii, na którą zwróciłem uwagę $\mathrm{w}$ książce, nie polega (wbrew sugestiom Błażeja Gębury) na przekształceniu się nieidolatrycznego doświadczenia źródłowego w doświadczenie idolatryczne, lecz na tym, że założyciel lub reformator religijny sam staje się (wbrew woli) obiektem czci, przysłaniając Boga, którego głosił. Nawet założyciel religii bowiem nie dysponuje doświadczeniem wolnym od wszelkich idoli; z jednej strony pojmuje Boga zgodnie z własną, skończoną naturą, z drugiej — jest w stanie przekazać swoje doświadczenie innym jedynie za pomocą skończonych form językowych. $Z$ tego powodu późniejsi wyznawcy nowej religii nie mają dostępu do pierwotnego doświadczenia; nie tyle zatem obcują z Bogiem, ile naśladują osobę, której zaufali. Potwierdzeniem jest rola Jezusa w chrześcijaństwie; próbując przywrócić pierwotne doświadczenie bliskości Boga, zagubione w prawnym formalizmie, po swojej śmierci stał się obiektem czci jako Mesjasz (a nawet Wcielony Bóg). Analogiczna sytuacja miała miejsce w dziejach Kościoła; początkowo Apostołowie i ich następcy uważali się za uczniów Jezusa, z czasem jednak przejęli jego zbawcze prerogatywy, przypisując sobie władzę kluczy. W ten sposób już nie tylko Bóg jest święty, lecz także Kościół, występujący w Jego imieniu; nie Chrystus też otwiera przed ludźmi bramy nieba, lecz kler, przypisujący sobie prawo odpuszczania grzechów. Dochodzi zatem do odwrócenia ról między Kościołem a Bogiem: nie Bóg jest fundamentem, założycielem i celem Kościoła, lecz Kościół reglamentuje Boga w postaci sakramentów, wpływając na fakt i sposób Jego obecności w świecie (Eucharystia) ${ }^{9}$. Do podobnej przemiany doszło $\mathrm{w}$ islamie, $\mathrm{w}$ którym reformator $\mathrm{z}$ czasem przysłonił

\footnotetext{
${ }^{9}$ Te złożone procesy deifikacji Jezusa oraz zawłaszczenia Boga przez Kościół opisał wnikliwie Tomasz Polak w książce System kościelny czyli przewagi pana K. (PolaK 2020). Omówienie książki, zatytułowane „Chrześcijaństwo: powstanie i upadek mitu. Na marginesie książki Tomasza Polaka System kościelny”, opublikowałem w czasopiśmie Studia Philosophica Wratislaviensia (ZIEMIŃSKI 2020a).
} 
Allaha; skoro bowiem tylko prorokowi objawione zostało boskie prawo, należy go czcić na równi z Bogiem. Jeszcze wyraźniej widać to na przykładzie Koranu; początkowo był jedynie świętą księgą prawa, z czasem jednak samo prawo stało się obiektem czci. $Z$ tego powodu można sądzić, że islam nie jest teokracją, lecz nomokracją, nie Bóg bowiem jest jego centrum, lecz Prawo (por. NASR 1988). W taki sposób dochodzi do zastąpienia Boga przez narzędzia pośredniczące, które miały Go odsłaniać. Degeneracja religii nie polega zatem na jej uspołecznieniu, lecz na zastąpieniu właściwego obiektu czci przez idole.

Argument odwołujący się do „religii zero” opiera się na jeszcze innym wątpliwym założeniu. Błażej Gębura sugeruje bowiem, że pierwotna postać religii nie ma charakteru społecznego, lecz prywatny. Polemista suponuje zatem, że idolatria pojawia się dopiero wtedy, gdy źródłowe doświadczenie religijne założyciela zostaje upublicznione. Problem polega jednak na tym, że nie istnieje prywatna religia, podobnie jak nie istnieje prywatny język. Gdyby zatem pojawił się człowiek pretendujący do tego, że miał bezpośrednie doświadczenie Boga, wolne od idolatrii, to inne osoby mogłyby je uznać za wiarygodne dopiero wtedy, gdyby zostało poddane intersubiektywnym procedurom weryfikacyjnym. Znaczy to, że nawet „religia zero” jest z konieczności społeczna, a nie prywatna. Wprawdzie jest logicznie możliwe pomyśleć osobę mającą nieidolatryczne doświadczenie Boga, to jednak dopóki nie stwierdzimy jej faktycznego istnienia i nie poddamy jej doświadczeń epistemicznej kontroli, nie mamy podstaw do uznania jej roszczeń za prawdziwe. W takim zaś razie trudno uznać „religię zero” za element jakiejkolwiek religii historycznej; sam Błażej Gębura zresztą nie zilustrował jej żadnym przykładem ${ }^{10}$.

\footnotetext{
${ }^{10}$ Podobne przykłady podaje Marcin Iwanicki, odwołując się do rozmowy telefonicznej jako modelu interpretacji doświadczeń religijnych, jak bowiem nikt nie myli rozmówcy z telefonem, tak wierzący nie myli idola z Bogiem; w obu przypadkach mamy do czynienia z poznaniem bezpośrednim (w pierwszym przypadku za pomocą łączy telefonicznych, w drugim - za pośrednictwem stworzeń). Przykład ten jest jednak kłopotliwy, jeśli bowiem rozumieć go dosłownie, to należy zauważyć, że ludzie religijni raczej nie rozmawiają z Bogiem przez telefon; jeśli zaś rozumieć go analogicznie, to nie ma wątpliwości, że rozmowa telefoniczna jest jedynie namiastką obecności, ponieważ głos w słuchawce nie zastąpi kontaktu bezpośredniego. Na szczęście z wielu osobami, z którymi rozmawiamy przez telefon, możemy (i chcemy) spotkać się też bezpośrednio; w przypadku Boga jest to niemożliwe. Równie kłopotliwy jest inny przykład podany przez Marcina Iwanickiego, dotyczący sposobów kontaktowania się ze świadomymi komputerami przez ich konstruktorów. Przyznając się do ignorancji w dziedzinie informatyki, nie rozumiem, w jaki sposób świadome komputery (i przy jakim rodzaju świadomości im przypisanej) mogłyby pomóc przezwyciężyć religijną idolatrię.
} 


\section{PRZYPADKOWY AKT CZCI}

Kolejny przykład rzekomo nieidolatrycznego aktu religijnego, podany przez Błażeja Gęburę, ma charakter dendrologiczny; zdaniem Polemisty bowiem człowiek podziwiający najwyższe drzewo na świecie w rzeczywistości nieświadomie czci Boga. Samowiedza nie ma w tym przypadku znaczenia, liczy się bowiem jedynie obiektywne odniesienie podziwu; w ten sposób subiektywny zachwyt estetyczny nad drzewem staje się obiektywnie aktem religijnej czci.

Wbrew nadziejom Polemisty przykład ten jest kłopotliwy, trudno bowiem imputować człowiekowi podziwiającemu najwyższe drzewo na świecie, że ulega złudzeniu, w rzeczywistości czcząc Boga. Nieuprzedzony obserwator dostrzeże w podanym przykładzie raczej estetyczny zachwyt nad pięknem przyrody niż nieidolatryczny akt czci; religijnie może go zinterpretować jedynie ktoś, kto wierzy w Boga jako stwórcę świata, uznając zarazem, że każdy podziw okazywany stworzeniu jest zarazem podziwem dla jego Autora. Gdyby zresztą Błażej Gębura miał rację, to należałoby przyjąć, że doświadczenia religijne redukują się do doświadczeń innego typu — estetycznych lub nawet dendrologicznych; w takim zaś razie ich przedmiotem nie jest Bóg, lecz stworzenia. Trudno w tej sytuacji zaprzeczyć, że są idolatryczne; człowiek przecież, który nieświadomie czci Boga pod postacią drzewa, w rzeczywistości podziwia skończoną rzecz fizyczną w świecie. Pojawia się zatem aporia: albo przypadkowy akt czci nie jest aktem religijnym, albo jest idolatryczny.

Omawiany przykład jest problematyczny także z innego powodu. Gdyby bowiem każdy zachwyt nad wyjątkowym obiektem był przypadkowym i nieświadomym aktem czci Boga, to również osoba podziwiająca najwyższy budynek na świecie oddawałaby religijną cześć jego twórcom. Taką jednak deifikację architektów i budowniczych trudno uznać za zachowanie religijne.

Kolejną trudnością jest kwestia symbolicznej przemocy stosowanej przez teistę wobec człowieka podziwiającego najwyższe drzewo na świecie. Podobna sytuacja miałaby wszak miejsce wtedy, gdyby wyznawca judaizmu przekonywał chrześcijan, że chociaż sądzą, że czczą Mesjasza, to jednak w rzeczywistości czekają dopiero na Jego przyjście. Wprawdzie subiektywnie wierzą, że Jezus był Synem Bożym, to jednak obiektywnie uznają Go za uzurpatora i bluźniercę, którego słusznie zabito. Podobnie mogliby argumentować wyznawcy islamu, przekonując chrześcijan, że czczą Jezusa jako jednego z proroków, w rzeczywistości bowiem nie wierzą w Trójcę 
Świętą, tylko w Allaha. Trudno jednak oczekiwać, że wyznawcy Chrystusa porzucą swoje „subiektywne” przekonania na rzecz ich wykładni „obiektywnej”, podanej przez wyznawców innych religii. Równie trudno oczekiwać od człowieka zachwycającego się najwyższym drzewem na świecie, że uzna słuszność teistycznej interpretacji swego doświadczenia.

Idea nieświadomego aktu czci dostarcza także silnego oręża krytykom religii, widzącym w niej irracjonalny zabobon lub zło. Nic przecież nie stoi na przeszkodzie, aby akt religijny, subiektywnie przeżywany jako cześć oddana Bogu, został obiektywnie zinterpretowany jako bluźnierstwo. Przykładem jest spożywanie postaci eucharystycznych jako ciała i krwi Chrystusa; krytyk mógłby wszak dowodzić, że katolicy spożywają jedynie chleb i wino, w przeciwnym bowiem razie należałoby ich oskarżyć o udział w uczcie totemicznej (czy nawet w akcie kanibalizmu). Podobnie można dowodzić, że odziani w szaty liturgiczne i tonący w dymach kadzideł kapłani ulegają złudzeniu, wierząc, że oddają cześć Bogu; w rzeczywistości biorą udział $\mathrm{w}$ happeningu lub nawet $\mathrm{w}$ obrzędach magicznych, niezrozumiałych dla osób postronnych. Krytyk jednak, który posunąłby się do takiej interpretacji zachowań osób wierzących, mógłby zostać oskarżony o obrazę uczuć religijnych. Przykład podany przez Błażeja Gęburę uruchamia niestety lawinę podobnych interpretacji, które nie służą obronie religii, lecz potwierdzają jej idolatryczność. Panteista przecież mógłby powiedzieć, że podziw dla drzewa jest aktem czci oddawanej przyrodzie lub immanentnemu jej logosowi, który nie ma nic wspólnego z osobowym Bogiem Stwórcą. Wyznawca animizmu mógłby sądzić, że jest to akt czci dla potężnego i groźnego demona, skrytego w najwyższym drzewie. Satanista zaś mógłby dowodzić, że tylko szatan był w stanie powołać do istnienia tak wspaniałe drzewo, wobec czego ten, kto je podziwia, czci szatana. Interpretację taką może wzmacniać Biblia, zgodnie z którą szatan potrafi naśladować działania Boga, udając anioła światłości (2 Kor 11,14). Podobnie Jezus ostrzegał Apostołów przed fałszywymi prorokami, którzy będą nauczać w Jego imieniu (Mt 7,15).

Przywołane interpretacje są równie możliwe jak interpretacja teistyczna; ich źródłem jest nadmierne lekceważenie świadomości ludzi — zarówno tych, którzy przeżywają zachwyt estetyczny nad przyrodą, jak i tych, którzy wierzą, że spełniają akty religijnej czci. Ludzie wierzący zresztą najczęściej wiedzą, że idole, z którymi obcują, nie są Bogiem; na tym jednak polega dramat wiary, że nie jest możliwe bezpośrednie poznanie Boga ani oddawanie $\mathrm{Mu}$ czci bez pośrednictwa idoli. Wprawdzie subiektywna świadomość nie może być argumentem rozstrzygającym $\mathrm{w}$ ocenie tego, co jest przedmiotem doświadczeń 
danej osoby (każdy bowiem może ulec iluzji), to jednak nie należy jej całkowicie lekceważyć; w szczególności nie należy sakralizować ludzkich doświadczeń, zwłaszcza tak dalekich od religii, jak podziw dla drzewa (nawet najwyższego $)^{11}$. Warunkiem uznania go za nieświadomy akt religijnej czci byłoby przedstawienie dowodu, że teistyczna interpretacja jest jedyną możliwą (a przynajmniej najbardziej zasadną). Należałoby też wykazać, że mamy tu do czynienia $\mathrm{z}$ aktem nieidolatrycznym, to znaczy, że osoba podziwiająca drzewo nie widzi obiektu przyrodniczego, lecz Boga; takiego dowodu jednak Polemista nie podał, wobec czego można sądzić, że ludzkie akty religijne są nieuchronnie idolatryczne, niezależnie od tego, czy mają charakter świadomy i celowy czy nieświadomy i przypadkowy.

\section{DYSTANS ONTYCZNY}

Kolejny zarzut Błażeja Gębury dotyczy konieczności istnienia dystansu ontycznego między Bogiem a człowiekiem jako warunku możliwości nawiązania relacji religijnej ${ }^{12}$. Polemista próbuje sprowadzić do absurdu wymóg bezpośredniego dostępu do obiektu religijnej czci, sugerując, że w takim wypadku możliwa byłaby jedynie cześć oddawana Bogu przez samego Boga. $\mathrm{Z}$ tego powodu transcendencję Boga należy rozumieć w taki sposób, aby z jednej strony — ocalić Jego nieskończoność i odrębność od świata, z drugiej — zachować bliskość, pozwalającą Go czcić.

W odpowiedzi należy zauważyć, że (sugerowana przez Polemistę) kuriozalność czy dziwność ${ }^{13}$ czci oddawanej Bogu przez samego Boga jest cechą charakterystyczną zarówno teizmu filozoficznego (zwłaszcza arystotelesow-

${ }^{11}$ Konsekwentne lekceważenie ludzkiej samowiedzy jako iluzorycznej i zastępowanie jej interpretacjami obiektywnymi doprowadziłoby do zrujnowania naszego obrazu świata; jeśli bowiem ludzie nigdy nie wiedzą, co czynią, to można dowolnie interpretować wszystkie ich zachowania.

${ }^{12}$ Zdaniem Marcina Iwanickiego dystans ontyczny nie wyklucza możliwości poznania Boga; spieszę dodać, że w książce dystans jest rozumiany także epistemicznie.

${ }^{13}$ Pomijam fakt, że dziwność jakiegokolwiek poglądu nie musi oznaczać jego fałszywości (a przynajmniej braku zasadności). W dziejach filozofii zresztą nie brakowało poglądów dziwacznych, przynajmniej z punktu widzenia wiedzy potocznej; przykładem może być iluminizm Augustyna, monadologia Leibniza, okazjonalizm Malebranche'a czy spirytualizm Berkeleya. Z kolei nadmierne przywiązanie do zdrowego rozsądku, cechujące chociażby Reida, mogłoby doprowadzić do uznania za prawdę wszystkiego, co oglądamy zmysłami; nauka świadczy tymczasem, że byłoby to zwodnicze. Argument $\mathrm{z}$ dziwności jednak należy szczególnie ostrożnie stosować w badaniach nad religią, która z definicji wykracza poza obszar codziennych przekonań. Negując zatem wszelką dziwność (cudowność), trudno byłoby wierzyć we wcielenie, śmierć, zmartwychwstanie i wniebowstąpienie Syna Bożego. 
skiego), jak i chrześcijańskiego. Zgodnie wszak z poglądami Stagiryty tylko Bóg jest adekwatnym przedmiotem poznania i miłości Boga, wobec czego nie wie On nawet o istnieniu czegokolwiek poza Nim. Podobnie teiści chrześcijańscy zakładają, że Boga może w pełni poznać jedynie Bóg; skoro zaś warunkiem miłości (przejawiającej się także w aktach czci) jest poznanie, to tylko Bóg potrafi w pełni kochać (czcić) Boga ${ }^{14}$.

Podobny problem wiąże się z postulatem zmiany pojęcia boskiej transcendencji. Bóg przecież, aby skutecznie pomagać ludziom, powinien być wszechwiedzący, doskonale dobry i wszechmocny (czyli radykalnie różny od świata); problem w tym, że wykracza wówczas poza możliwości naszego poznania. Obiekt religijnej czci jest zatem z natury niespójny: albo pojmiemy go jako byt radykalnie transcendentny, nie mogąc nawiązać z nim bezpośredniej relacji, albo jako rzecz skończoną, podobną do Zeusa na Olimpie $^{15}$. Jedynym sposobem wyjścia $z$ tego dylematu jest religia jako idolatria, czyli oddawanie czci transcendentnemu Bogu za pośrednictwem przysłaniających Go idoli.

W tym kontekście zarzut sformułowany przez Błażeja Gęburę można potraktować nie tyle jako podważenie tezy książki, ile jej dodatkowe uzasadnienie, okazuje się bowiem, że religia albo jest idolatrią, albo jest niemożliwa. Jeśli bowiem Bóg jest radykalnie transcendentny, to jest nieosiągalny; z kolei próba osłabienia Jego transcendencji prowadzi nieuchronnie do idolatrii. W gruncie rzeczy bowiem postulat Błażeja Gębury polega na detronizacji (a przynajmniej dezabsolutyzacji) Boga, w wyniku czego zostaje On skrojony na ludzką miarę; sugeruje to, że człowiek stwarza swoich bogów na własny obraz i podobieństwo. Takie rozwiązanie jednak podważa sens istnienia religii jako pragnienia Nieskończoności (absolutnej świętości); wydaje się tymczasem, że człowiek nie chce czcić stworzonych przez siebie bożków, nad którymi ma władzę, lecz nieskończonego Boga, który istnieje obiektywnie. Nawet jeśli pragnienie to jest niemożliwe do spełnienia, to jednak wskazuje, że człowiek stara się przekroczyć swoją skończoność, wybiegając myślą w kierunku niedosiężnego absolutu. Religia ukazuje w ten sposób metafizyczne rozdarcie ludzkiego bytu — zarówno w jego nędzy, jak

${ }^{14} \mathrm{Z}$ tego zapewne powodu Tomasz z Akwinu przekonywał (za Augustynem), że Bóg najbardziej kocha Chrystusa, który — jako jego Jednorodzony Syn — jest prawdziwym Bogiem. Por. Tomasz z Akwinu, Suma teologiczna, I, q. 20, a. 3-4 (Tomasz z Akwinu 1975, 162-167). Skoro jednak Bóg może (a nawet musi) siebie kochać, to może też siebie czcić.

${ }^{15}$ Szerzej pisałem na ten temat w popularnym artykule „Problem Boga - między mitem a abstrakcją" (ZIEMIŃSKi 2015, 6-8). 
i próbach jej przełamania ${ }^{16}$. Osłabienie boskiej transcendencji sprawi tymczasem, że popadniemy w idolatrię, Boga nie znajdując. Wprawdzie ludzie potrafią siebie oszukiwać, to jednak na dłuższą metę życie w kłamstwie jest kłopotliwe; $\mathrm{z}$ tego powodu można mieć nadzieję, że religijne idole będą systematycznie demaskowane i porzucane. Dramat człowieka polega jednak na tym, że zastąpią je inne idole (niekoniecznie świeckie, wbrew sugestii Marcina Iwanickiego).

\section{UNIWERSALNOŚĆ (POJĘCIA) IDOLATRII}

Zdaniem obu Polemistów nadmierne rozszerzenie pojęcia idolatrii na wszystkie zjawiska religijne (a nawet kulturowe), powoduje, że traci ono sens; o idolatrii bowiem można mówić tylko wtedy, gdy istnieją akty nieidolatryczne.

W odpowiedzi należy zauważyć, że pojęcie idolatrii (religijnej czy nawet kulturowej) funkcjonuje podobnie do wszystkich pojęć ogólnych, zwłaszcza esencjalnych. Przykładem jest pojęcie człowieka jako istoty cielesnej, obejmujące wszystkich ludzi i wskazujące na konieczną cechę bytu ludzkiego. Trudno je uznać za pozbawione znaczenia tylko dlatego, że nie zostało skontrastowane z przykładami ludzi niemającymi ciała (czystymi duchami); skoro bowiem człowiek nie może istnieć bez ciała, to rozszerzenie pojęcia cielesności na cały rodzaj ludzki jest w pełni zasadne. Podobnie jest w przypadku idolatrii jako jedynej formy istnienia religii; skoro idolatryczność jest cechą esencjalną wszystkich zjawisk religijnych, to trudno żądać podania przykładu zjawiska religijnego, które nie jest idolatryczne ${ }^{17}$.

Kwestionując uniwersalność pojęcia idolatrii, Polemiści wskazują na jej stopniowalność, dowodząc, że nie wszystkie religie są idolatryczne w takim

\footnotetext{
${ }^{16}$ Napięcie to dobrze oddał Marcin Iwanicki, przywołując postać Syzyfa i bohaterów Becketta.

${ }^{17}$ Doceniam erudycję Marcina Iwanickiego, który powołuje się na — nieznaną mi — filipikę Berkeleya, zgodnie $\mathrm{z}$ którą jeśli coś jest problemem dla wszystkich, to nie jest problemem dla nikogo. Wprawdzie brakuje mi literackiego talentu, aby odpowiedzieć Polemiście równie zgrabnie pod względem retorycznym, to jednak nie mam wątpliwości, że Berkeley fatalnie się pomylił. Fakt przecież, że wojny, terroryzm czy zmiany klimatyczne są problemem dla wszystkich ludzi, nie znaczy, że nie są problemem dla nikogo; przeciwnie, jeśli są problemem dla wszystkich, to są problemem dla wszystkich. Podważenie uniwersalności pojęcia idolatrii miałoby zresztą także niepożądane konsekwencje dla różnych wersji teizmu; jeśli bowiem kreacjonista twierdzi, że Bóg stworzył wszystkich ludzi, to — idąc tropem rozumowania Polemisty — nie stworzył nikogo.
} 
samym stopniu. Szczególnie ważnym elementem ma tu być świadomość idolatrii, która towarzyszy wielu wierzącym; skoro zatem człowiek wie, że poznaje Boga jedynie pośrednio i cząstkowo, to nie grozi mu utożsamienie idola z właściwym obiektem czci. Inaczej mówiąc, Polemiści przekonują, że kto jest świadomy idolatryczności religii, już się z idolatrii wyzwolił.

Argument ten nie tylko nie falsyfikuje głównej tezy książki, lecz ją wzmacnia; człowiek religijny przecież, który wie, że obcuje z idolami, a nie z Bogiem, nie wyzwolił się z idolatrii, lecz potwierdził jej obecność w aktach czci. Źródłem idolatrii nie jest wszak brak skupienia czy zapomnienie, komu oddajemy cześć, lecz struktura aktu religijnego, który nigdy Boga w Nim samym nie osiąga. Człowiek świadomy idolatrii zatem, chociaż wie, że idol nie jest Bogiem, to jednak wie również, że nie z Bogiem obcuje, tylko z reprezentującym Go idolem. Wprawdzie świadomość ta pozwala uniknąć utożsamienia Boga $\mathrm{z}$ idolem, nie oznacza jednak, że osoba religijna zna Boga; w ścisłym sensie wie tylko, że idol nie jest Bogiem. Mamy zatem ponownie do czynienia z sytuacją analogiczną do (przywołanej wyżej) epistemologii Kanta; świadomość, że znamy tylko zjawiska jako różne od rzeczy w sobie, nie oznacza, że znamy również rzeczy w sobie; przeciwnie, nadal znamy tylko zjawiska i wiemy, że znamy tylko zjawiska. Podobnie osoba religijna, świadoma idolatrii, której ulega, wie, że zna tylko idole, nie zaś Boga, nawet jeśli tych idoli z Bogiem nie utożsamia.

\section{POSTULAT ELIMINACJI RELIGII}

Dostrzegając w książce Religia jako idolatria skrajny pesymizm, Marcin Iwanicki upatruje w niej także postulatu eliminacji religii z kultury; wprawdzie Autor zarzutu przyznaje, że postulat ten nie jest wypowiedziany explicite, to jednak ma wynikać z przekonania, że idolatria jest fałszem, którego miłośnik prawdy powinien unikać. Skoro zatem nie jest możliwa religia nieidolatryczna, to należy ją porzucić, uwalniając się od zgubnego fałszu (nawet jeśli nadal nie będziemy znać prawdy).

Odpowiadając na tę trudność, należy zaznaczać, że wywody zawarte w książce Religia jako idolatria nie są oceną religii ani dążeniem do jej eliminacji, lecz opisem sposobu funkcjonowania zjawisk religijnych w ludzkim życiu. Podstawowym celem książki była eksplikacja biblijnej tezy, zgodnie z którą „Boga nikt nigdy nie widział” (J 1,18). Jest to zatem opis ludzkiej przygodności, która objawia się w różnych sferach kultury, także 
$\mathrm{w}$ religii ${ }^{18}$. To jednak, że nie możemy obcować z prawdą (a jedynie z lepiej czy gorzej potwierdzonymi teoriami naukowymi) ani z pięknem (lecz tylko bardziej czy mniej udanymi dziełami sztuki), nie oznacza, że powinniśmy wykluczyć z naszego życia naukę czy sztukę. Podobnie fakt, że nie możemy obcować z Bogiem (świętością), a tylko z idolami, nie oznacza, że powinniśmy wyzbyć się religii. Równocześnie jednak świadomość, że kultura jest niedoskonałym tworem ludzkim, powinna uczyć pokory i ostrożności w absolutyzacji jakiejkolwiek konkretnej tradycji kulturowej i postponowaniu innej. Skoro bowiem wszyscy jesteśmy zamknięci w świecie własnych idoli, to nie powinniśmy sobie uzurpować prawa do znajomości absolutnej prawdy (czy boskiego objawienia), odmawiania zaś jej innym ${ }^{19}$. Z tego właśnie powodu starałem się wskazać nie tylko na istotową idolatryczność religii, lecz także nieuchronną idolatryczność jej krytyki. Nie znaczy to jednak, że musimy popaść w skrajny relatywizm, nie wszystkie bowiem idole są jednakowo błędne (a tym bardziej - jednakowo groźne). Idol filozoficznej dysputy, polegającej na poszukiwaniu niedosiężnej prawdy, wydaje się mniej groźny od idola jedynego objawienia boskiego, poznanego przez wyróżnioną wspólnotę religijną, dążącą do narzucenia jej całemu światu ${ }^{20}$. Przestrogą przed takim stanowiskiem powinny być wojny wszczynane przez różnych fundamentalistów religijnych (tak w przeszłości, jak współcześnie). Podobną prze-

${ }^{18}$ Ten wątek został znakomicie dostrzeżony w omówieniu książki, podpisanym inicjałami D.Ch., zamieszczonym w czasopiśmie Ethos 33 (2020), nr 3 (191), 320-322.

${ }^{19}$ Przejawem takiego myślenia jest encyklika Ut unum sint, w której pada jednoznaczne stwierdzenie, że pełnia Kościoła, zamierzonego przez Boga, istnieje tylko we wspólnocie rzymskokatolickiej, w pozostałych zaś - jedynie cząstkowo. Por. JAN PAWEe II, Ut unum sint, nr 14. W podobnym duchu redagowano dokumenty soborowe; wprawdzie Kościół potępia w nich prześladowania, domagając się wolności wyznania i pratykowania religii, to jednak pełnię świętości i prawdy przypisuje tylko sobie, żądając równocześnie prawa do nieskrępowanego głoszenia Ewangelii wszystkim ludom na całym świecie. Por. Sobór Watykański II. Konstytucje. Dekrety. Deklaracje. Tekst polski, a tam: Dekret o Kościołach Wschodnich Katolickich (s. 181-191); Dekret o ekumenizmie (s. 203-218); Deklaracja o stosunku Kościoła do religii niechrześcijańskich (s. 334-338); Deklaracja o wolności religijnej (s. 414-426); Dekret o działalności misyjnej Kościoła (s. 436-474). Soborowy język nie jest językiem dialogu, lecz nauczania; nie wynika to jednak z megalomanii księży czy teologów, lecz z istoty chrześcijaństwa, idea jedyności i pełni objawienia wyklucza bowiem dialog jako wspólne poszukiwanie prawdy. Szerzej pisałem na ten temat w tekście „O (niemożliwości) dialogu między religiami” (ZIEMIŃSKI 2016, 243-258). Dialog taki jest ewidentnie możliwy na gruncie religii pluralistycznej. Por. ОвIREк 2015.

${ }^{20}$ Bardzo udaną i wartą dalszego rozwijania próbą uwolnienia religii (zwłaszcza chrześcijaństwa) z rozmaitych idoli metafizycznych czy epistemologicznych (w tym dogmatycznie rozumianej wiecznej i niezmiennej prawdy obiektywnej) jest filozofia religii uprawiana przez ks. Krzysztofa Śnieżyńskiego; spełnia ona zarazem warunek filozoficzności, jak i religijności. Por. ŚNIEŻYŃSKI 2016, 105-198. 
strogą powinien być kolonializm, oznaczający nie tylko eksploatację i wyzysk ekonomiczny, lecz także narzucanie podbitym ludom własnej kultury.

W świetle tych uwag nie ma wątpliwości, że lepszy jest świat pluralizmu kultur (w tym religii) niż świat jednej, narzuconej wszystkim prawdy. Podobnie lepszy jest świat, w którym istnieje wiele poglądów na religię (nawet tak różnych jak moje i moich Polemistów), niż jedna, oficjalna wykładnia natury religii. Idola pluralizmu szczególnie powinni cenić filozofowie, nie ma wszak wątpliwości, że świat, w którym istnieje tylko jedna philosophia perennis, jest uboższy niż świat wielu wzajemnie się ścierających stanowisk ${ }^{21}$. $Z$ tego samego powodu nie należy postulować eliminacji religii; stąd przecież, że jest nieuchronnie idolatryczna, nie wynika konieczność porzucenia wszelkich wierzeń czy rytuałów. Odrzucić fałsz jest racjonalne wtedy, gdy odkryliśmy prawdę; skoro jednak w przypadku religii prawda jest nieosiągalna, porzuconego fałszu nie mielibyśmy czym zastąpić. Nie znając religii wolnej od idolatrii, mamy do wyboru jedynie porzucenie jednej grupy idoli na rzecz innej lub idoli religijnych na rzecz idoli świeckich. W takim jednak razie postulat całkowitej eliminacji religii z kultury mógłby być szkodliwy, czasami bowiem lepiej wyznawać użyteczny egzystencjalnie fałsz (zdając sobie z tego sprawę), niż go odrzucić, skazując się na sceptyczne zawieszenie.

Dodatkową okolicznością, nakazującą ostrożność w postulowaniu eliminacji religii, jest to, że nie wiemy, która religia jest fałszywa we wszystkich swoich aspektach. Wprawdzie każda jest nieskuteczna jako próba nawiązania bezpośredniego kontaktu z Bogiem, to jednak stąd nie wynika konieczność porzucenia wszystkich religijnych praktyk czy wierzeń. Nie wiemy zresztą, jak wyglądałby świat, z którego wszystkie religie zostałyby usunięte - czy byłby lepszy od obecnego, czy gorszy. Powodem jest to, że nie da się jednoznacznie ocenić wpływu religii na ludzkie zachowania. Dobrym przykładem jest historia Maksymiliana Kolbe; nie sposób wszak ustalić, czy wyrazem żarliwej wiary mnicha był jego przedwojenny antysemityzm, czy wyjątkowy akt heroizmu w obozie koncentracyjnym, kiedy oddał życie za współwięźnia. Jeśli zatem mamy spróbować dokonać w miarę sprawiedliwej oceny religii, musimy odwołać się do różnych kryteriów jej akceptowalności. Najważniejszym z nich nie jest jednak stopień idolatryczności; wprawdzie lepsza jest religia mniej idolatryczna, to jednak zdecydowanie ważniejszą kwestią jest to, czy stosuje przemoc. Idolatria jest złem godnym potępienia dopiero wtedy,

\footnotetext{
${ }^{21}$ Pogląd ten jest też bliski Marcinowi Iwanickiemu, który odżegnuje się od myślicieli, dla których ostateczną wykładnią prawdy jest Suma teologiczna Tomasza z Akwinu.
} 
gdy oznacza składanie ofiar z ludzi lub zwierząt bądź prowadzi do prześladowania wyznawców innych religii ${ }^{22}$. $Z$ tego powodu najważniejszym kryterium oceny religii jest kryterium etyczne, zakazujące krzywdzenia istot świadomych i czujących; jeśli bowiem Bóg istnieje, to nie może chcieć cierpień, zwłaszcza dokonywanych w Jego imię.

W ocenie religii należy też uwzględnić kryterium racjonalności; bardziej akceptowalna jest zatem ta religia, która głosi obraz świata wolny od baśniowości. Wprawdzie ludzie często oczekują od bogów działań cudownych, to jednak tylko taka religia jest w stanie pomóc, która nie łudzi iluzjami, stawiając swoich wyznawców wobec rzeczywistego dramatu życia. Lepsza jest zatem religia ukazująca świat przez czarny monokl niż przez różowe okulary, trzeba wszak znać nędzę ludzkiej kondycji, żeby móc zastosować skuteczne (a nie tylko cudowne) lekarstwo. Boga nie należy zrównywać ze świętym Mikołajem, przynoszącym prezenty, ani z czarodziejem, który uzdrawia z wszelkich chorób, a po śmierci oferuje raj obfitości.

Religie należy też oceniać pod kątem gwarantowania przez nie autonomii świętości; lepszą jest zatem ta religia, która nie mnoży (zwłaszcza osobowych i instytucjonalnych) pośredników między Bogiem i ludźmi, występujących w Jego imieniu, a nawet reglamentujących Go. Autentyczna religia bowiem to bezinteresowny kult Boga (świętości) tylko dlatego, że istnieje i że jest Bogiem (świętością); nie dlatego zatem winniśmy Go czcić, że tak nam nakazał czy że obiecał nam życie wieczne, lecz dlatego, że jest (o ile jest). Warunkiem istnienia oraz praktykowania tak rozumianej religii nie są żadne dogmaty ani magiczne rytuały; nie jest też potrzebna wyróżniona kasta kapłanów ani teologów, cieszących się uprzywilejowaną pozycją we wspólnocie wyznawców. Religia to po prostu akt czci, ukierunkowany na Boga (świętość), nawet jeśli nie jest Go w stanie osiągnąć. Im mniej zatem pośredników na drodze człowieka do Boga, tym lepiej. W świetle tego

\footnotetext{
${ }^{22}$ Zdaniem Tomasza z Akwinu idolatria jest grzechem najcięższym. „Podobnie [...] jak w ziemskiej rzeczypospolitej najcięższym występkiem wydaje się składanie królewskiej czci nie prawdziwemu królowi, ale komuś innemu, gdyż kto tak postępuje w miarę swych możności burzy cały ustrój państwa - tak największym grzechem przeciw Bogu wydaje się składanie boskiej czci stworzeniu, gdyż ten kto ją składa, usiłuje niejako kogo innego uczynić na świecie bogiem z uszczerbkiem królowania prawdziwego Boga" (Tomasz z Akwinu, Suma teologiczna, II-II, q. 94, a. 3 - Tomasz z Akwinu 1971, 182). Problem oddania większej czci stworzeniu niż Stwórcy jest tematem noweli Sienkiewicza Przez stepy. Bohater, który kochał żonę bardziej niż Boga, musiał ją - z wyroku Najwyższego — stracić; z tego powodu Bóg jawił mu się nie jako dobry ojciec, lecz jako zazdrosny okrutnik. W tej sytuacji bohaterowi noweli pozostaje tylko nadzieja na połączenie $\mathrm{z}$ ukochaną w niebie; oczekiwaną przez niego treścią życia wiecznego nie jest jednak Bóg, lecz żona. Por. Sienkiewicz 1989, t. 2, 82-133.
} 
wniosku jest oczywiste, że nie należy eliminować religii, lecz jedynie przywrócić jej właściwe miejsce w kulturze i ludzkim życiu. Nie dogmaty bowiem, rytuały czy instytucje powinny stać w centrum religii, lecz świętość.

$\mathrm{Z}$ tego powodu religia musi respektować autonomię człowieka, nie zawłaszczając kolejnych etapów życia i nie poddając ich idolatrycznym obrzędom (od narodzin po śmierć). $Z$ tej nadmiernej rytualizacji ironizował św. Augustyn, krytykując rzymski politeizm. Nawet ślub czy noc poślubna nie była wszak wolna od niezbędnej ingerencji bogów, co sprawiało, że religia stawała się karykaturą samej siebie ${ }^{23}$. Z podobną sytuacją mamy do czynienia także $w$ innych religiach, poddających idolatrycznym obrzędom urodzenie człowieka, nadanie mu imienia, wejście w związek małżeński, chorobę czy umieranie ${ }^{24}$. Wszystkie te sformalizowane rytuały jednak nie mają nic wspólnego z oddaniem Bogu bezinteresownej czci. Zamiast auten-

${ }^{23}$ Augustyna drażniła nie tylko konieczność zatrudniania wielu bóstw w celu realizacji najdrobniejszej czynności, lecz także nadmierna sakralizacja ludzkiego życia. „Kiedy mężczyzna i kobieta związki małżeńskie zawierają, służy do tego bóg Jugatynus (Związywacz). No, można to jeszcze wyrozumieć. Ale otóż trzeba pannę młodą wprowadzić do domu. Wykonuje to znów bóg Domidukus (Dowódca); żeby zaś młoda pani pozostawała w domu, dopomaga do tego Domitius (Domownik); aby z mężem przebywała, dodana jest do pomocy bogini Manturna (Przebywanna). Czegoż chcieć jeszcze więcej? Uszanować by trzeba wstydliwość ludzką. Niechby już reszty dokonała pożądliwość ciała i krwi, uczciwszy tajemnicę wstydu! Po kiegoż licha cały tłum bożków i bogiń zapełnia jeszcze łożnicę, kiedy już nawet weselnicy z niej wychodzą? A zapełnia nie dlatego, by myśl o ich tam przebywaniu była ku pomocy wstydliwości, lecz dlatego, by słabe młode dziewczę, zalęknione z powodu nowych dla siebie rzeczy, pozbawione było bez przeszkód dziewictwa przy pomocy tych bóstw. Bo oto stawają do pomocy: bogini Virginensis (Dziewicza) i bóg ociec-Subigus (Podkładnik) i bogini matka Prema (Tłoczka), i bogini Pertunda (Przebijaczka, i Wenus, i Priapus. Cóż to ma znaczyć? Jeżeli całkowicie nad tą sprawą zatrudniony mąż potrzebowałby jeszcze pomocy bóstw, czyżby nie wystarczył jakiś jeden bóg lub jedna bogini? Czyżby nie dosyć było samej Wenery, która podobno, od tego też ma swoje miano, że bez siły (vis) kobieta nie przestałaby być dziewicą (virgo)? Jeżeli ludzie mają jakiekolwiek poczucie wstydu, które bogom jest obce, to czyż nowożeńcy, gdy wierzą, że tyle bóstw obojga płci jest obecnych i wtrącających się do tej czynności, nie spłoną wstydem aż do tyla, że on słabnie w pobudliwości, a ona więcej się broni? No i rzeczywiście, jeśli jest już bogini Virginensis (Dziewicza), by dziewczę szat pozbawić, jeśli jest bóg Subigus (Podkładacz), by ją mężowi podsunąć; jeśli jest bogini Prema (Tłoczka), by podsuniętą tak mocno przytulić, iżby się nie kręciła - to cóż tu jeszcze robi Pertunda (Przebijaczka)? A wstyd! A za drzwi z nią!" (Św. Augustyn, Państwo Boże, VI, 9 - Augustyn 1998, 240-241).

${ }^{24}$ Kościół rzymski zawłaszczył — przez swoją praktykę sakramentalną — niemal każdy etap ludzkiego życia: chrzest, Eucharystia, okresowe wyznanie win, pokuta, bierzmowanie, małżeństwo, kapłaństwo, kolejne rocznice przyjęcia sakramentów, wiatyk, pogrzeb, a nawet regularne modlitwy za zmarłych, mające mieć wpływ na ich losy pośmiertne. Do tego dochodzi wyraźny brak zgody na zapłodnienie in vitro, co powoduje, że los jednostki poddany jest niemal bez reszty ingerencji religijnej instytucji; w skrajnym przypadku rytualny wpływ zaczyna się przed poczęciem i trwa wiele wieków po śmierci. 
tycznej religii mamy idolatrię, zamiast sakralizacji ludzkiego życia zaś — profanację świętości.

W świetle tego wniosku jest oczywiste, że religia (słusznie żądając autonomii dla siebie) musi także zapewnić autonomię innym dziedzinom kultury $^{25}$. W pierwszej kolejności religia nie może ingerować w badania naukowe (i to także dotyczące jej samej, zwłaszcza jej powikłanych dziejów). W praktyce oznacza to, że instytucje religijne nie mogą sobie uzurpować prawa do recenzowania odkryć naukowych jako rzekomo zgodnych lub niezgodnych $\mathrm{w}$ boskim objawieniem (i to nawet w postaci tak zwanej normy negatywnej). Zasada autonomii musi też obejmować medycynę (w tym psychiatrię), trudno wszak zgodzić się na leczenie chorób (fizycznych lub psychicznych) za pomocą modlitw czy egzorcyzmów. Religia nie powinna też ingerować w zasady stanowienia prawa (wyborczego, spadkowego, podatkowego czy karnego) ani kształtować instytucji społecznych, chociażby małżeństwa ${ }^{26}$. W równej mierze religia powinna respektować autonomię sztuki, nie ingerując $\mathrm{w}$ treść poszczególnych dzieł nawet, jeśli wydają się niereligijne (czy antyreligijne) ${ }^{27}$. Przykłady te jednoznacznie wskazują, że lepszą i bardziej akceptowalną religią jest ta, która oznacza odniesienie człowieka do świętości, rezygnując z zawłaszczania innych dziedzin kultury. Biorąc zatem pod uwagę ludzką skończoność (zwłaszcza ograniczenia ontyczne, epistemiczne i moralne), optymalną religią jest ta, która czyni nas lepszymi, niż bylibyśmy bez niej. W praktyce oznacza to przestrzeganie tylko jednej zasady: pozwól żyć innym, nie narzucaj im swoich bogów i nie uzurpuj sobie prawa do posiadania absolutnej prawdy zbawczej.

${ }^{25}$ Różne wymiary owej autonomii wnikliwie i wszechstronnie opisują nie tylko filozofowie, lecz także socjologowie religii. Por. MAJCHEREK 2015.

${ }^{26}$ Żadna religia nie powinna narzucać ludziom jednego modelu małżeństwa, odwołując się do rzekomo boskiego prawa czy też stworzonego przez Boga porządku naturalnego. Przykładem jest małżeńskie prawo islamskie, wyjątkowo niesprawiedliwe dla kobiet, dopuszcza bowiem wielożeństwo. Podobnie niesprawiedliwa jest — wobec osób LGBTQIA — zasada chrześcijańskiego małżeństwa jako związku kobiety i mężczyzny. Jak trafnie zauważa Marcin Iwanicki, nie wynika ona $\mathrm{z}$ doktryny chrześcijańskiej, należąc do elementów przygodnych i zmiennych. Zamiast jednak odróżniać elementy istotne od przygodnych, lepiej wyłączyć życie intymne z jakiejkolwiek jurysdykcji religijnej, nawet zliberalizowanej; małżeństwo jest instytucją społeczną (nie zaś religijną), wobec czego należy poprzestać na regulacjach państwowych. Nie ma też wątpliwości, że mitologiczny tekst sprzed kilku tysięcy lat, proklamujący stworzenie mężczyzny i kobiety (Rdz 1,27), nie może być miarodajnym wyznacznikiem badań nad zagadnieniem płci. Złożoność tych zagadnień dostrzega także Marcin Iwanicki.

${ }^{27} \mathrm{Z}$ tego powodu nieszczęśliwie się stało, że prymas Wyszyński surowo oceniał (nie jako koneser sztuki, lecz jako kapłan) przedstawienie teatralne Grotowskiego Apocalypsis cum figuris, upatrując w nim parodii mszy świętej; podobnie nie powinien był potępiać jako (rzekomo niemoralnego) dramatu Różewicza Białe malżeństwo. Por. OBIREк 2020, 35-39. 


\section{BIBLIOGRAFIA}

Augustyn, św. 1998. Państwo Boże. Przeł. Władysław Kubicki. Kęty: Wydawnictwo Antyk.

ČAPEK, Karel. 2015. Fabryka Absolutu. Przeł. Paweł Hulka-Laskowski. Wydanie czwarte (dodruk). Warszawa: Dowody na istnienie. Wydawnictwo, Instytut Reportażu.

Frankowska, Maria. 1987. Mitologia Azteków. Warszawa: Wydawnictwa Artystyczne i Filmowe. GĘBuRA, Błażej. 2021. „O (domniemanej) idolatryczności religii”. Roczniki Filozoficzne 69, nr 4: 357-365 (tekst z tego numeru $R F$ ).

IwANICKI, Marcin. 2021. „Religia przez czarny monokl”. Roczniki Filozoficzne 69, nr 4: 367-380 (tekst $\mathrm{z}$ tego numeru $R F$ ).

JAN PaweŁ II. [1995] 2005. Encyklika Ut unum sint. W: Encykliki Ojca Świętego Jana Pawła II, 989-1077. Kraków: Wydawnictwo Znak, 2005.

Judycki, Stanisław, i Tadeusz SzubKa. 1985. „Irracjonalne przedzałożenia czy racjonalna intuicja intelektualna (w związku z książką J. Życińskiego Teizm i filozofia analityczna)". Zeszyty Naukowe KUL 28, nr 3-4, s.143-153.

MAJCHEReK, Janusz Andrzej. 2015. Bóg bez znaczenia. Stare Groszki: Wydawnictwo CiS.

NASR, Seyyed Hossein. 1988. Idee $i$ wartości islamu. Przeł. Janusz Danecki. Warszawa: Instytut Wydawniczy PAX.

OBIReK, Stanisław. 2015. Polak katolik? Stare Groszki: Wydawnictwo CiS.

OBirek, Stanisław. 2020. Wąska ścieżka. Dlaczego odszedtem z Kościoła. Stanistaw Obirek w rozmowie z Arturem Nowakiem. Warszawa: Wydawnictwo Agora.

Pismo Święte. Stary i Nowy Testament, red. Michał Peter i Marian Wolniewicz. Poznań: Księgarnia św. Wojciecha, 2005.

Polak, Tomasz. System kościelny czyli przewagi pana K. 2020. Poznań: Wydawnictwo Nauk Społecznych i Humanistycznych Uniwersytetu im. Adama Mickiewicza.

Sienkiewicz, Henryk. 1989. Przez stepy. W: Henryk Sienkiewicz. Nowele. T. 2, 82-133. Warszawa: Państwowy Instytut Wydawniczy.

Sobór Watykański II. Konstytucje. Dekrety. Deklaracje. Tekst polski. Poznań: Wydawnictwo Pallottinum, [b.r.w.] — dokumenty: Dekret o Kościołach Wschodnich Katolickich (181191); Dekret o ekumenizmie (203-218); Deklaracja o stosunku Kościoła do religii niechrześcijańskich (334-338); Deklaracja o wolności religijnej (414-426); Dekret o działalności misyjnej Kościoła (436-474).

ŚNIEŻYŃSKI, Krzysztof. 2016. „Metafizyka w roli pasożyta w Winnicy Pańskiej? Dekonstrukcyjne uwagi na temat próby ratowania metafizyki (filozofii bytu) kosztem chrześcijaństwa w pometafizycznej kulturze". W: Metafizyka i dekonstrukcja. W poszukiwaniu doświadczenia metafizycznego w kontekście wyzwań dekonstrukcjonizmu, red. Krzysztof Śnieżyński i Piotr Duchliński, 105-198. Kraków: Akademia Ignatianum i Wydawnictwo WAM.

Tomasz z AKwinu. 1971. Suma teologiczna, t. 19: Religijność. Przeł. Feliks W. Bednarski. Londyn: Veritas.

Tomasz z Akwinu. 1975. Suma teologiczna, t. 2: O Bogu, cz. II. Przeł. Pius Bełch, Londyn: Veritas.

Ziemiśski, Ireneusz. 2015. „Problem Boga - między mitem a abstrakcją”. Filozofuj nr 6: 6-8.

ZIEMIŃSKI, Ireneusz. 2016. „O (niemożliwości) dialogu między religiami”. Ethos 19, nr 1 (113): $243-258$.

ZIEMIŃSKI, Ireneusz. 2020a. „Chrześcijaństwo: powstanie i upadek mitu. Na marginesie książki Tomasza Polaka System kościelny”. Studia Philosophica Wratislaviensia 15, fasc. 4: 93-107.

ZIEMIŃSKI, Ireneusz. 2020b. Religia jako idolatria. Esej filozoficzny o nieuchronności elementów idolatrycznych w religii. Szczecin: Wydawnictwo Uniwersytetu Szczecińskiego. 


\section{O RZECZYWISTEJ I NIEUCHRONNEJ \\ IDOLATRYCZNOŚCI RELIGII — ODPOWIEDŹ POLEMISTOM}

Streszczenie

Krytyka tez zwartych w mojej książce Religia jako idolatria, przedstawiona w polemikach autorstwa Błażeja Gębury i Marcina Iwanickiego, jest zasadniczo nietrafna. Głównym powodem jest to, że Autorzy zarzutów nie przedstawili żadnego historycznego przykładu zjawiska religijnego niebędącego idolatrią. Odwołując się jedynie do przykładów logicznie możliwych (można niesprzecznie pomyśleć akt religijnej czci, który nie byłby idolatryczny), nie podali warunków, jakie musiałyby zostać spełnione, aby ów akt mógł zostać urzeczywistniony; tymczasem podstawowym z nich jest zmiana ontycznego i epistemicznego statusu człowieka jako istoty zdolnej bezpośrednio obcować z Bogiem. Również podane przez Polemistów bardziej szczegółowe argumenty nie obalają tezy o nieuchronnej idolatryczności religii. Jeśli bowiem Bóg przyjmuje wszystkie akty czci, składane Mu w dziejach, to należy Go oskarżyć o łamanie elementarnych zasad moralnych, trudno bowiem zaakceptować krwawe ofiary składane Mu z ludzi i zwierząt. Z kolei „religia zero” jest niemożliwa do spełnienia; z jednej strony okazuje się fenomenem całkowicie prywatnym (analogicznym do prywatnego języka), z drugiej — oznacza poznanie Boga na sposób ludzki (jest zatem idolatryczna, co przyznaje także Autor zarzutu). Podobnie nieświadomy akt czci (podziw dla najwyższego drzewa na świecie) jest doznaniem estetycznym, a nie religijnym; teistyczna interpretacja tego aktu nosi znamiona przemocy symbolicznej, a także redukuje doświadczenia religijne do poczucia piękna. Nie ma też wątpliwości, że postulowany przez Polemistów dystans ontyczny jako konieczny warunek religii nieidolatrycznej w rzeczywistości ją uniemożliwia, ponieważ nawet Bóg nie jest w stanie objawić się nam takim, jaki jest, lecz musi się dostosować do naszych ograniczeń poznawczych; może się zatem objawić jedynie jako nie-Bóg. $Z$ tego powodu każdy akt religijny jest nieuchronnie idolatryczny; nie oznacza to jednak (wbrew opinii Polemistów) nadużycia słowa „idolatria” do zjawisk religijnych, lecz właściwy opis ich natury. Mimo to nie należy całkowicie eliminować religii z życia społecznego; dopóki bowiem ludzie religijni nikogo nie krzywdzą i nie próbują narzucać swoich idoli innym osobom, mają prawo bez przeszkód w nie wierzyć, a nawet je czcić.

Słowa kluczowe: religia; idolatria; Bóg; akt czci; kultura.

\section{ON THE ACTUAL AND UNAVOIDABLE IDOLATRY OF RELIGION: AN ANSWER TO POLEMICIANS}

\section{Su m mary}

The critiques of arguments I presented in Religia jako idolatria. Esej filozoficzny o nieuchronności elementów idolatrycznych $w$ religii [Religion as idolatry: A philosophical essay on the inevitability of idolatrious elements in religion], authored by Błażej Gębura and Marcin Iwanicki, are fundamentally inaccurate. The main reason being that the authors of the critiques have not put forth any historical example of a religious phenomenon which was not idolatry. They only referred to logically possibly examples (it is admittedly possible to conceive of an act of religious worship which would not be idolatrical), yet they did not provide the conditions which would have to be fulfilled for this act to materialize; meanwhile the primary condition would be to change the ontic and epistemic status of humans as beings capable of direct contact with God. The more detailed arguments presented by my polemicians also do not disprove the claim that it is unavoidable for religion to be idolatrical. For if God accepts all acts of worship throughout 
history, He should be charged with defying fundamental moral principles; it is after all difficult to accept the bloody human and animal sacrifices he received. Furthermore, "religion zero" is impossible to actualize; on one hand it is a completely private phenomenon (analogous to a private language), on the other it means knowing God in a human way (and thus is idolatrical, as even the Author of the charge admits). Similarly, an unconscious act of worship (admiration for the tallest tree in the world) is an aesthetic experience, not a religious one; a theistic interpretation of this act bears the markings of symbolic violence and reduces religious experiences to experiencing beauty. There is no doubt that ontic distance as a necessary condition of non-idolatrical religion, proposed by the polemicians, actually makes it an impossibility. Even God cannot reveal Himself to us the way $\mathrm{He}$ is, but instead He must adhere to our cognitive limitations and thus can only reveal Himself as a non-God. Therefore, any religious act is unavoidably idolatrical; however, contrary to the claims by my Polemicians, this is not an overuse of the term "idolatry" in relation to religious phenomena, but rather an accurate description of their nature. Despite this, one should not eliminate religion entirely form social life; as long as religious people pose no harm to others and do not attempt to force their idols onto others, they have the right to freely believe and worship them.

Keywords: religion; idolatry; God; culture; act of worship.

Information about the Author: Prof. Dr. habil. Ireneusz ZiemińsKi - University of Szczecin, Faculty of Humanities, Institute of Philosophy and Cognitive Science; correspondence address: ul. Krakowska 79, 71-017 Szczecin; e-mail: Ireneusz.Zieminski@usz.edu.pl; ORCID: https://orcid.org/0000-0003-4686-8625. 